\title{
DE PAN-AMERIKAANSCHE UNIE.
}

DOOR

JHR. L. C. VAN PANHUYS.

Wij staan aan den vooravond van een toeneming van het verkeer, zooals voor de uitvinding van het vliegtuig niet kon worden voorzien. Wijst dit op de kans tot grootere toenadering onder de volken, zoo heeft de wereldbrand ons ook een instituut gebracht (wij bedoelen den Volkenbond) dat, samenwerking belovende in vele dingen, de volgende geslachten naar wij hopen, ook zal opvoeden tot het koesteren van gedachten van internationale eenheid.

Voor het Westelijk Halfrond bestaat reeds sedert jaren eene instelling die vrede en vriendschap onder de staten van de Nieuwe Wereld beoogt. Tot nog toe heeft men, noch in het Moederland, noch in de West-Indische koloniën, zich met die Amerikaansche instelling ingelaten. De tijd breekt aan, dat men er zich rekenschap van zal moeten geven, of het wenschelijk is op deze wijze nauwer verbinding te krijgen in de eerste plaats met de „United States” en ook met staten als Brazilië, Venezuela, Columbia en Mexico.

Wij achten het voor de toekomstige belangen van Suriname en Curaçao van belang het oog te richten op dien Amerikaanschen Bond, de "Pan-American Union”.

Het is een ambtelijk (officieel) verbond van de 21 onafhankelijke republieken van Noord- en Zuid-Amerika, die te Washington is gevormd tot ontwikkeling van handel, scheepvaart en verkeer, van betrekkingen met elkander en tot behoud, zooals gezegd, van vrede en vriendschap onder die staten. De Bond wordt be- 
stuurd door den Staatssecretaris van de Vereenigde Staten van Noord-Amerika, die voorzitter is krachtens zijn ambt en door de te Washington aanwezige diplomatieke vertegenwoordigers van de andere Amerikaansche gemeenebesten; de administratie wordt gevoerd door een directeur-generaal, die door het Bestuur gekozen, een internationaal ambtenaar is en wordt bijgestaan door een uitgebreiden staf van speciale deskundigen en andere ambtenaren, die inlichtingen inwinnen, onderzoekingen instellen, verslagen voorbereiden en openbaar maken, vragen beantwoorden, bezoekers rondleiden en briefwisseling voeren. Het gebouw te Washington, een van de schoonste van de Vereenigde Staten, is door bijdragen van Carnegie, die 750.000 dollars schonk, en van de gezamenlijke republieken gesticht, als een fraai symbool van Pan-Amerikaansche solidariteit en saamhoorigheid.

Nauwkeurige inlichtingen over de republieken worden, opdat die landen beter bekend zullen worden, openbaar gemaakt door het gëillustreerde maandschrift (Bulletin of the P.A.U.), dat in het Engelsch, Spaansch, Portugeesch en Fransch verschijnt en van allen vooruitgang in ieder Amerikaansch land melding maakt. Het bureau verspreidt pamfletten nopens allerlei onderwerpen betreffende de landen die tot de Unie zijn toegetreden en zendt die toe in antwoord op vragen van belanghebbende personen, firma's en instellingen.

In de bibliotheek, de „Columbus Memorial Library” zijn o.a. tal van gegevens over Latijnsch Amerika te vinden; op de tafels in de leeszaal zijn ook nieuwsbladen en maandschriften aanwezig. (Wellicht ook „De WestIndische Gids"?).

Van bijzonder belang is de Internationale Raad, die de Pan-Amerikaansche Unie tot een waren vredesbond van de Amerikaansche natiën stempelt. Op den eersten Woensdag van iedere maand komen in de Regeeringszaal van het gebouw, rond een groote ovale tafel, met stoelen waarop de namen en wapens van de betrokken landen, de Staatssecretaris van de U.S.A. en de diplo- 
matieke vertegenwoordigers van de andere republieken in rade bijeen.Daar worden de kansen op het nauwer aanhalen van de betrekkingen tusschen de republieken en de middelen tot het behoud van den vrede besproken. Mogelijk zijn door den zedelijken invloed van dezen Raad reeds ettelijke oorlogen op het Amerikaansche vastland voorkomen.

Het bureau van de Unie is van meening, dat het vooral aan zijn arbeid te danken is, dat de handel tusschen de U.S.A. en de 20 Latijnsch-Amerikaansche landen in de laatste twaalf jaren van naar schatting 500 millioen dollars tot 1 milliard, 750 millioen dollars is gestegen. De P.A.U. tracht door aanmoediging van de studie van het Spaansch en het Portugeesch, alsmede van de aardrijkskunde, geschiedenis en bijzonderheden van de Latijnsch-Amerikaansche landen, die staten populair te maken bij de onderwijsinstellingen in de U.S.A; zij heeft ook omgekeerd getracht hetzelfde te doen ten aanzien van de U.S.A. bij het onderwijs in de Latijnsche republieken.

Het bureau bevordert de uitwisseling van professoren en studenten aan de wederzijdsche hoogescholen en voorziet de nieuwsbladen van N. en $Z$. Amerika geregeld van inlichtingen betreffende de verschillende republieken, ten einde hen beter met die landen bekend te maken en er hunne belangstelling voor te wekken.

De Unie is dus een groote actieve organisatie voor de ontwikkeling van handel en beschaving, tot instandhouding van den vrede en een internationale vraagbaak voor de Nieuwe Wereld. Wie inlichtingen verlangt over Latijnsch-Amerika, van welken aard ook, kan zeker zijn een wel overwogen antwoord te ontvangen wanneer hij zich richt tot de Pan-American Union, Director General, Washington D.C.

De geschiedenis van deze merkwaardige organisatie dagteekent reeds van 1826 toen men vergeefs hoopte een „Panama Congres" tot stand te brengen van gedelegeerden van N.- Middel- en Z.-Amerika, en vragen van gemeenschappelijk belang te bespreken. Pogingen van 
Mexico (1831, 1838 en 1839), mislukten eveneens en een bijeenkomst van Bolivia, Chili, Ecuador, Nieuw-Granada en Peru in 1847/48 had geen resultaat, evenmin een bijeenkomst in 1856 te Santiago, waar Peru, Chili en Ecuador vertegenwoordigd waren. Mislukking viel ten deel aan een oproeping van Peru in 1846 om de voormalige Spaansche koloniën te vereenigen; ook toen in 1881, J. Blaine, Staatssecretaris van de U.S.A. een congres te Washington uitnoodigde, bleken de tijden daarvoor nog niet rijp te zijn. Eindelijk had in 1888 een door Cleveland bijeengeroepen Intern. Amerik. Conferentie plaats, die o.a. het instellen van arbitrage, eenheid van douane-bepalingen, gewichten, maten en gemeenschappelijke zilveren munt beoogde, alsmede gezamenlijke gezondheidsmaatregelen, doch slechts tot practische uitkomst had de oprichting van een Internationaal Bureau van de Amerikaansche Republieken. Het volgende congres had in 1901 plaats te Mexico, doch stelde de behandeling van vele zaken uit tot het Congres te Rio de Janeiro in 1906, waar o.a. de Dragoof Calvo-leer besproken werd, krachtens welke aan Regeeringen verboden werd private schulden door geweld te innen.

Maar ook deze bijeenkomst besloot vele punten over te laten, ditmaal aan de Haagsche Vredesconferentie.

In 1910 op de $4 \mathrm{e}$ zitting van de Conferentie te Buenos Aires, werd de naam Bureau van de Amerikaansche Republieken veranderd in „Pan American Union”.

Wanneer wij nu nog aanteekenen, dat Pan-Amerikaansche Wetenschappelijke Congressen bijeenkwamen in Chili, 1908, te Washington 1912; dat te Washington in 1915 op een P.A. Commercial Congress de wegen en middelen werden nagegaan om aan de oorlogsomstandigheden en de daaruit voor Amerika voortvloeiende handelsbelemmeringen tegemoet te komen, en dat in September 1920 te Chili weder een P.A. wetenschappelijk congres plaats vindt, dan beschikt men over genoeg gegevens om zich van de Unie een denkbeeld te kunnen maken. 
Totnogtoe zijn Engeland, Frankrijk en Nederland, de eenige niet-Amerikaansche Staten, die nog gebieden in de Nieuwe Wereld besturen, noch hunne koloniën tot de Unie toegetreden. Men stelle de vraag of dit, wat Nederland, Suriname en Curaçao betreft, zoo moet blijven, en of onze belangen, in dit opzicht, met die van Engeland en Frankrijk steeds zullen moeten samengaan.

Wellicht, dat in de toekomst een vertegenwoordiger van de N.W.I. koloniën ook zijn zetel in den Raad te Washington zal innemen.

Misschien zal tegen dien tijd de zetel van dien vertegenwoordiger kunnen worden versierd met de wapens van Suriname en Curaçao die dan mogelijk door een ook in dit opzicht actieve Regeering in het leven zullen zijn geroepen. 